\title{
Scanning and Transmission Electron Microscope Studies on the Organ of Corti and Stria vascularis in Human Fetal Cochlear Ducts
}

\author{
Sunao Fujimoto, Koji Yамамото, Ichiro Hayabuchi ${ }^{1}$ and Mitsuaki Yoshizuka ${ }^{2}$ \\ Department of Anatomy (Prof. S. Fujimoтo) ${ }^{1}$, University of Occupational and Environmental Health \\ School of Medicine, Kitakyushu and Department of Anatomy ${ }^{2}$, Kurume University School of \\ Medicine, Kurume, Japan
}

Received October 7, 1980

Summary. The organ of Corti in human fetuses aged 5 and 7 months, respectively, was observed with the scanning and transmission electron microscope (SEM and TEM).

By SEM observation, bulbous cytoplasmic structures protruding from the apical surface of the outer and inner hair cells were observed as was the case in SEM reports by others. By TEM observation, it was revealed that these structures are cytoplasmic projections from the so-called cuticular notch which, in adults, houses the basal body and is a site for synthesis of auditory stereocilia and a single kinocilium.

The stria vascularis was examined only in the 5 month specimen. The cytoplasm of the differentiating marginal cells is characterized by the presence of thick walled tubular membranes. The observation suggests that this tubular system may represent "a particular site" for secretion of some ions into the endolymph in the fetal condition.

Since the first description by CORTI (1851), there have been numerous ultrastructural studies made on the organ of Corti in various vertebrates (ENGSTRÖM, 1958; SMITH and SJöstrand, 1961; IUrato, 1961; Engström, Ades and Hawkins, 1962; Wersäll, Flock and Lundquist, 1965; Kimura, 1966; Smith, 1968; BredberG, Ades and Encström, 1972; Lim, 1972; Hoshino, 1973; ENGSTRöm, 1975). On the other hand, detailed ultrastructural observations on fetal and postnatal conditions of this organ have been very limited (Friedmann, 1969; Hoshino, 1974). Hoshino (1974), in his SEM study of the newborn kitten, demonstrated "globular processes" which protrude from the apical surface of the outer hair cells. Since such structures have never been observed in the adult specimens, they may occur only in the fetal condition and then disappear after the cells have been differentiated. However, TEM studies to clarify these processes have not been done and the significance of these structures is still uncertain.

This paper describes several findings on the organ of Corti and the stria vascularis of the differentiating cochlear ducts in human fetuses. Our SEM observations on the inner and outer hair cells demonstrate bulbous cytoplasmic processes similar to those found in the newborn kitten (Hoshino, 1974). Our TEM observations reveal that these structures are projections from the cuticular plate of the hair cells with 
a direct continuation of the plasma membrane and that auditory stereocilia are differentiated from them. The paper also includes brief observations of the stria vascularis, especially of thick walled tubular membrane system in the marginal cells and cells accumulated with glycogen particles.

\section{MATERIALS AND METHODS}

Two human fetuses ( 5 and 7 months) were obtained after their spontaneous abortion. Between 1 and 3 hrs after the abortion, they were perfused from the left ventricle with a mixture of $2.0 \%$ formaldehyde and $2.5 \%$ glutaraldehyde in $0.1 \mathrm{M}$ cacodylate buffer ( $\mathrm{pH}$ 7.4). Soon after the perfusion, the cochlear ducts were isolated from the internal ears and immersed in the fixative for $2 \mathrm{hrs}$.

For TEM study, specimens were post-fixed in $2 \%$ osmium tetroxide, dehydrated by acetone, and embedded in epoxy resins. Sections were made on a Porter-Blum MT-1 ultramicrotome, stained by uranyl acetate and lead acetate, and examined either in a Hitachi HU-12A or an H-500 electron microscope.

For SEM study, specimens were post-fixed in the same way as described above, dehydrated in ethanol, soaked in amyl acetate, dried by the critical point method using carbon dioxide, coated with gold palladium, and observed with a Hitachi S-700 field emission electron microscope.

\section{RESULTS}

\section{Bulbous structures of the differentiating hair cells}

SEM observations at 5 months revealed the existence of bulbous structures on the surface of the developing outer and inner hair cells (Fig. 1). Fibrous networks of the differentiating tectorial membrane extending from the epithelium of the spiral limbus are directly attached to the surface of these bulbous structures, and some fibrils of the tectorial membrane extend as far as the surface of the Hensen's cells (Fig. 1). Although the distribution of auditory stereocilia can hardly be seen by SEM at 5 months, their consistent location internal to the bulbous structures (side toward the spiral limbus) has already been observed in the 7 month specimen (Fig. 2). Each bundle of the stereocilia is composed of three to four rows and forms into almost a "W" with the base pointing toward the bulbous structures. A single kinocilium protrudes from the central region of the bulbous structures (Fig. 3). Some bulbous structures have been removed from the main cell surface in the 7 month specimen (Fig. 3).

By TEM observations in side views of the outer hair cells at 5 months, these bulbous structures are about $20 \mu \mathrm{m}$ in height and $6 \mu \mathrm{m}$ in diameter at the widest portion (Fig. 4). As has been already described above, they are in direct contact with the differentiating tectorial membrane. The stereocilia of each row show a stepwise increase in length with the longer ones toward the spiral prominence. However, even the tallest stereocilium of the outermost row does not reach the tectorial membrane at this month. Each stereocilium consists of electron opaque axial filaments continuous with the rootlet embedded in the cuticular plate (Fig. 4, 5). 

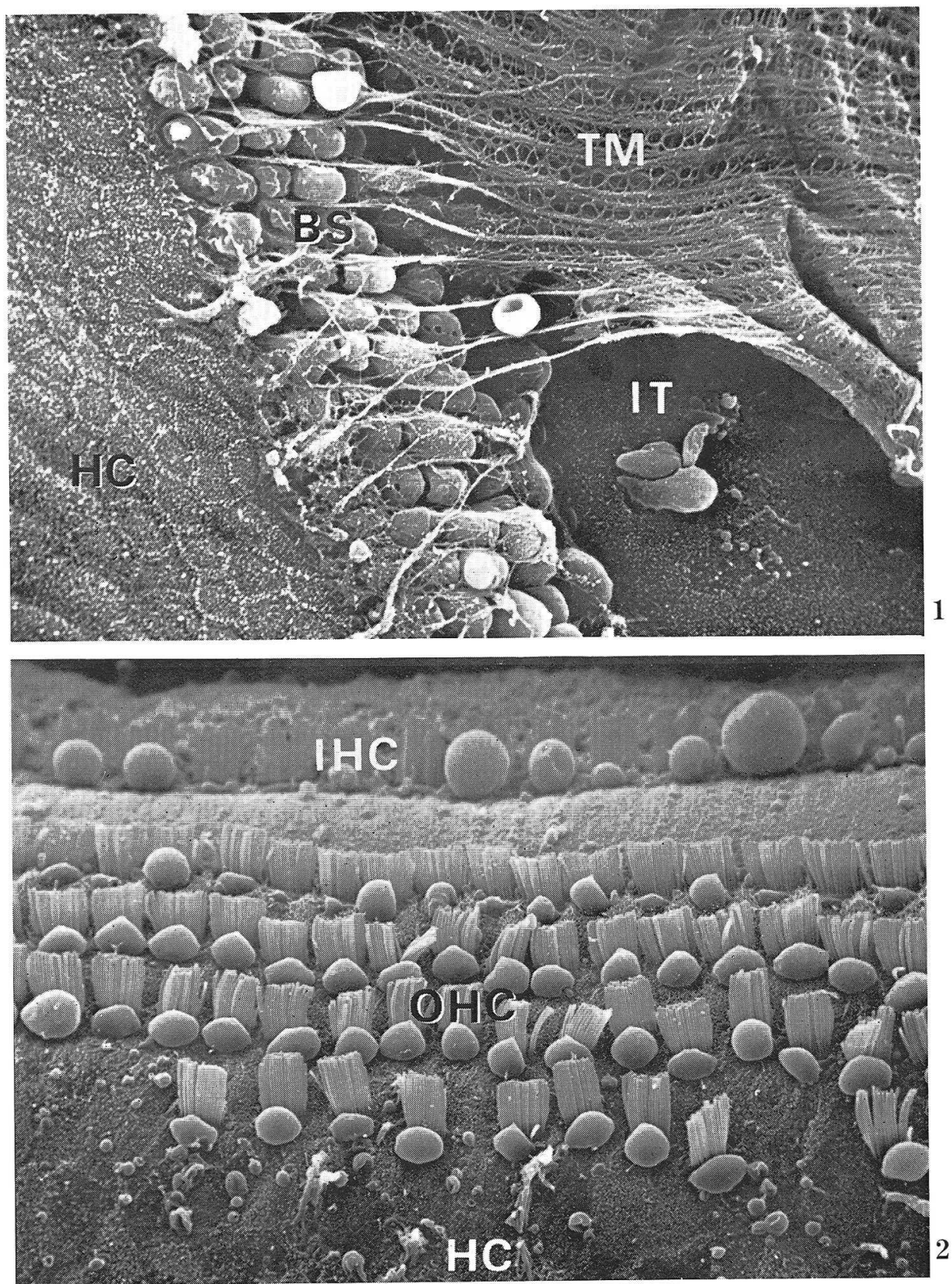

Fig. 1. Surface view of the organ of Corti at 5 months. Fibrillar networks of the tectorial membrane $(T M)$ are attached to bulbous structures $(B S)$ of the outer hair cells. Some fibrils of the tectorial membrane reach to the surface of the Hensen's cells $(H C)$. IT inner tunnel. $\times 860$

Fig. 2. Surface view of the inner $(I H C)$ and outer hair cells $(O H C)$ at 7 months. The stereocilia of both cells are almost arranged in a "W" form, the base of which faces the Hensen's cells $(H C)$. The bulbous structures of the hair cells always exist in the side toward the base of the "W". $\times 1,450$ 

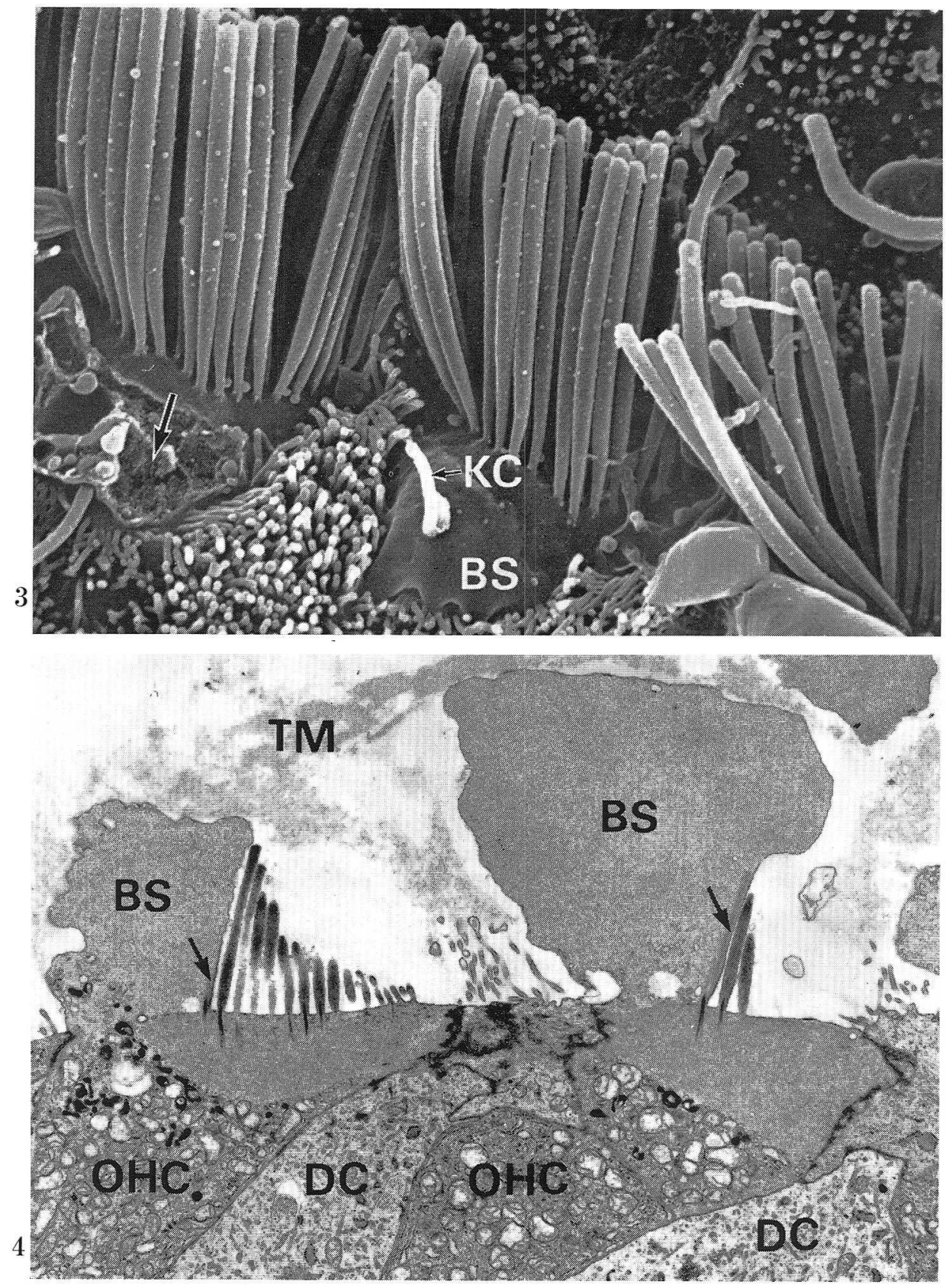

Fig. 3. Surface view of the outer hair cells at 7 months. A single kinocilium $(K C)$ extends from a bulbous structure $(B S)$. Another bulbous structure is detached from the main cell surface (arrow). $\times 8,600$

Fig. 4. Legend on the opposite page. 

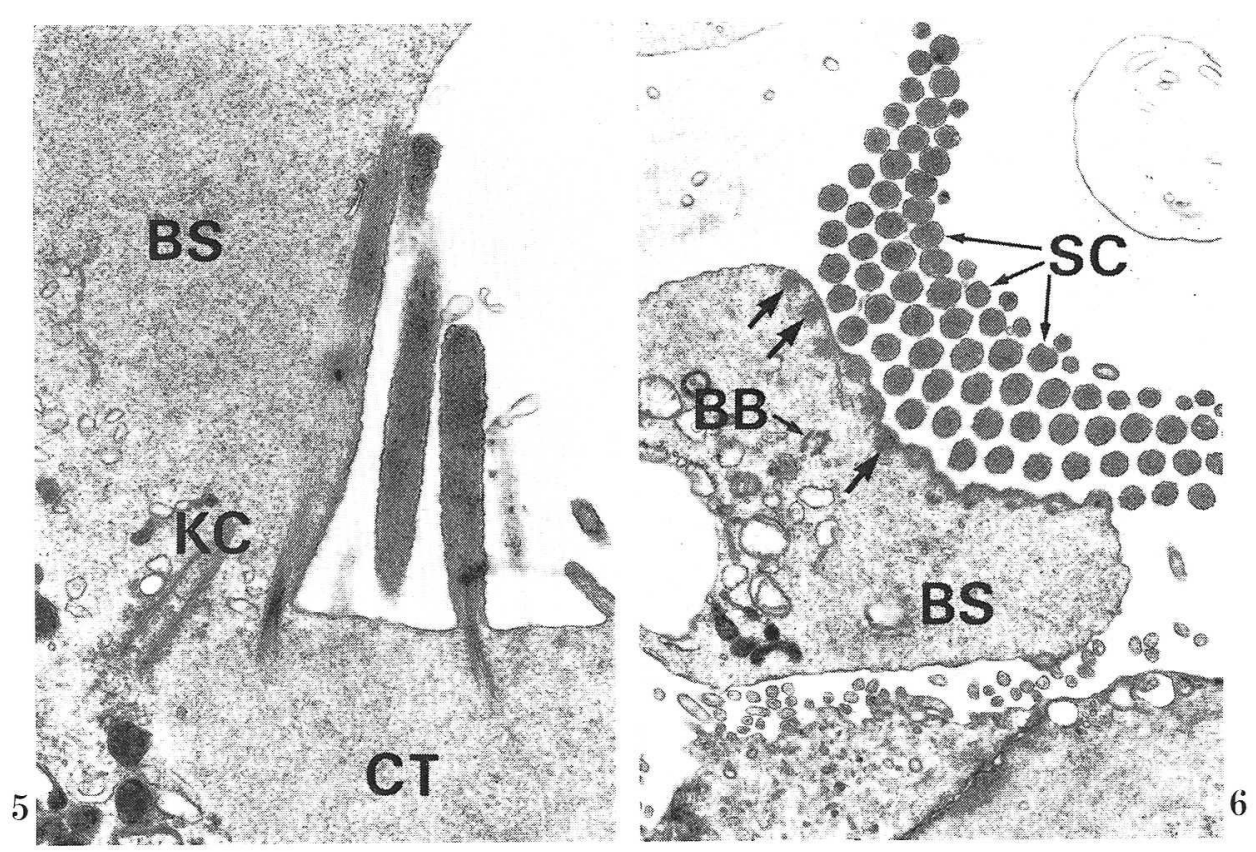

Fig. 5. A bundle of axial filaments is closely arranged along the plasma membrane of a bulbous structure $(B S)$ protruding from the cuticular plate $(C T)$ of an outer hair cell. The bulbous structure is almost occupied by fine fibrillar materials containing a few organelles. A single kinocilium $(K C)$ is distributed from the basal part of the bulbous structure. 5 months. $\times 14,000$

Fig. 6. A cross section of a bulbous structure $(B S)$ is shown. Three or four rows of stereocilia $(S C)$ are arranged in a "W" form. A basal body $(B B)$ is seen in the bulbous structure. Axial filaments of the stereocilia at the outermost row still exist in the bulbous structure along the plasma membrane (arrows). 5 months. $\times 10,000$

At 7 months, the bulbous structures have markedly decreased in size and the taller stereocilia of a few outer rows are in direct contact with the tectorial membrane (Fig. 9, 10). The top end of these attached stereocilia is surrounded by the plasma membrane of the hair cells with a slight increase in electron density.

The bulbous structures are very similar in general cytoplasmic features and electron density to the cuticular plate of the upper end of the hair cells. Our TEM pictures show that they are cytoplasmic projections from the so-called cuticular notch which, in adults, houses the basal body. The cytoplasm is almost occupied by irregularly arranged fine fibrils except for a few organelles such as ribosomes, small vesicles and mitochondria (Fig. 4-7).

The most characteristic feature of these bulbous structures is that the axial

Fig. 4. Sectioned view of bulbous structures (BS) protruding from the outer hair cells $(O H C)$ at 5 months. Fine fibrils of the tectorial membrane $(T M)$ are attached to the top of these bulbous structures. The stereocilia show a stepwise increase in length with the longer ones toward the bulbous structures. Axial filaments are arranged in the bulbous structures along the plasma membrane (arrows). The Deiters' cells $(D C)$ almost completely surround the outer hair cells. $\times 5,000$ 

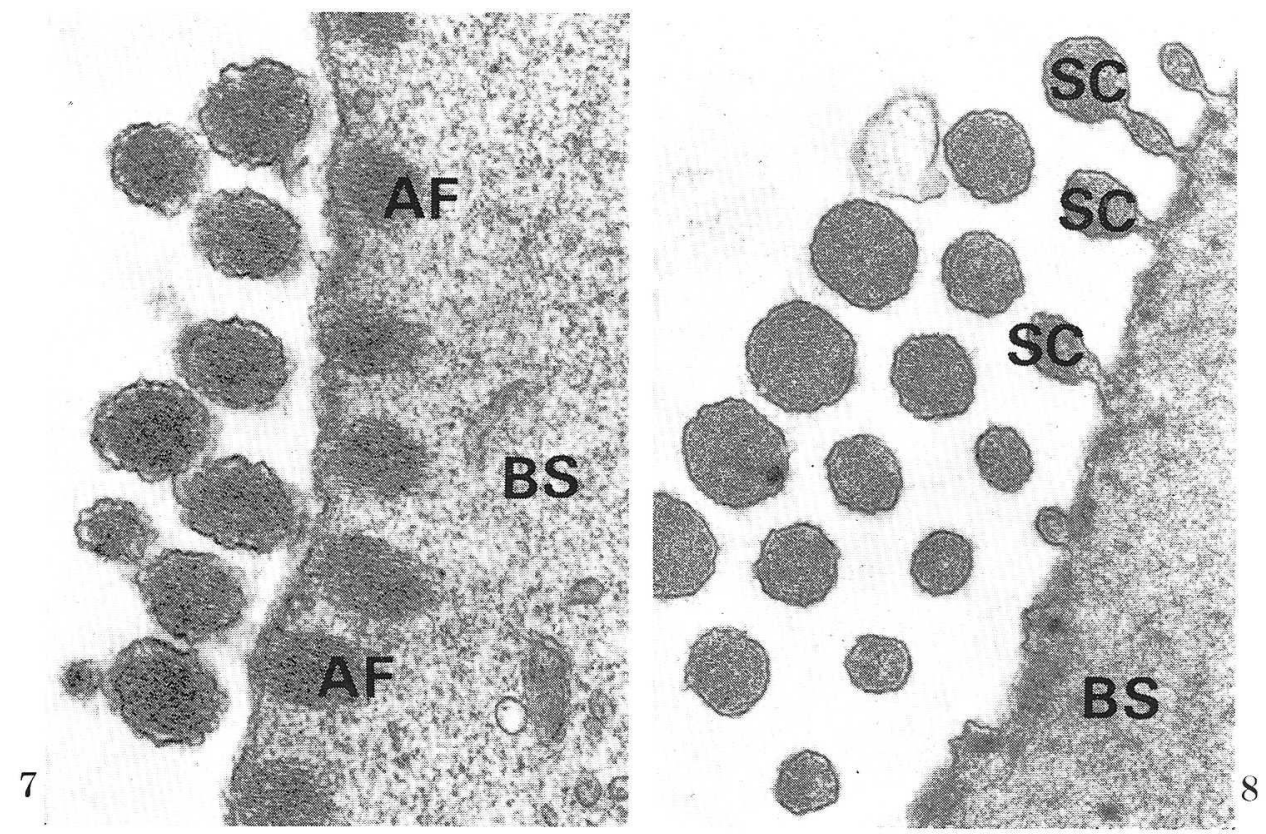

Fig. 7. A more highly magnified micrograph of axial filaments $(A F)$ in a bulbous structure (BS) as shown in Fig.6. 5 months. $\times 36,000$

Fig. 8. A cross section of a bulbous structure $(B S)$ is shown. Differentiating stereocilia (SC) at the outermost row are partially encircled by the plasma membrane of the bulbous structure. These stereocilia are still connected to the bulbous structure by a narrow stalk. 5 months. $\times 25,000$

filaments of the stereocilia differentiate in them (Fig. 4-8). Observing from longitudinal sections of the bulbous structures at 5 months, an axial filament bundle extends from the cuticular plate into the bulbous structures along the plasma membrane (Fig. 4-6). A single kinocilium also extends from the basal body locating in the external part of the cuticular plate into the bulbous structures (Fig. 5). In cross or rather oblique sections, the segregation process of the stereocilia by the bulbous structures was well observed. Many axial filament bundles of the differentiating stereocilia are arranged along the plasma membrane of each bulbous structure (Fig. $6,7)$. In some sections, they are partially encircled by indentations of the plasma membrane, and such differentiating stereocilia are connected to the bulbous structure by a narrow cytoplasmic stalk (Fig. 8).

Such formation processes of auditory stereacilia from the bulbous structures were not observed at 7 months. In this month, the bulbous structures have markedly reduced their size and contain many vacuoles which suggest the progression of degenerative changes (Fig. 9, 10). It is interesting that smooth cisterns frequently appear at the basal part of these bulbous structures (Fig. 10). If we consider SEM findings which show frequent detachments of the bulbous structures from the main cell surface (Fig. 3), the appearance of these cisterns may represent a demarcation process of the bulbous structures from the main cell body.

Many nerve endings which are in contact with the basal part of the outer and 

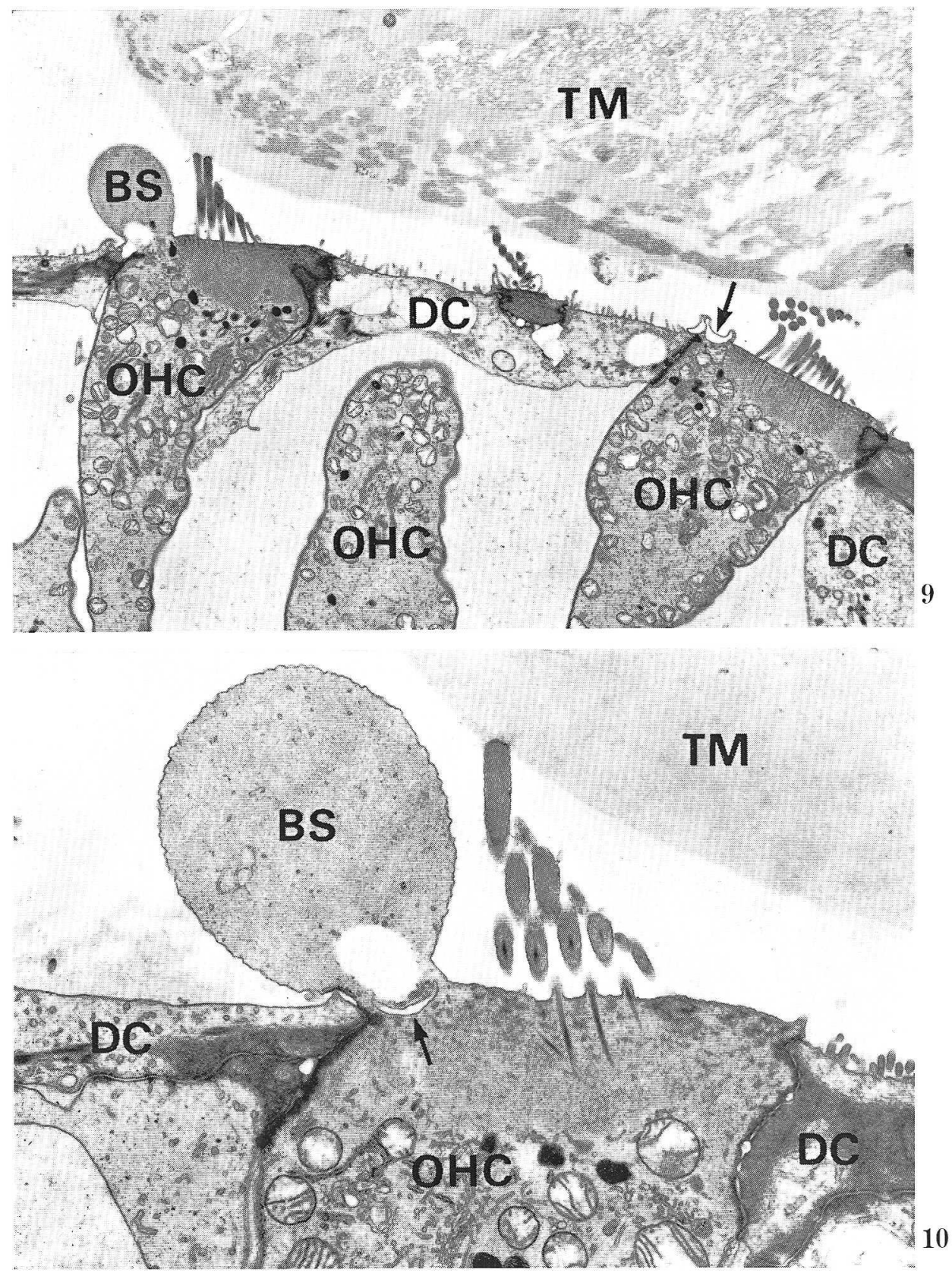

Fig. 9. A bulbous structure ( $B S)$ markedly decreased in size at 7 months. Another one seems to be detached from the main cell body (arrow). The taller stereocilia of a few outer rows are already in direct contact with the tectorial membrane $(T M)$. The outer hair cells $(\mathrm{OHC})$ are already wedged in by phalanges of the Deiters' cells $(D C)$. $\times 3,400$

Fig. 10. A cistern (arrow) appears at the base of a bulbous structure $(B S)$ of an outer hair cell $(O H C)$. TM tectorial membrane, $D C$ phalanges of Deiters' cell. 7 months. $\times 9,900$ 


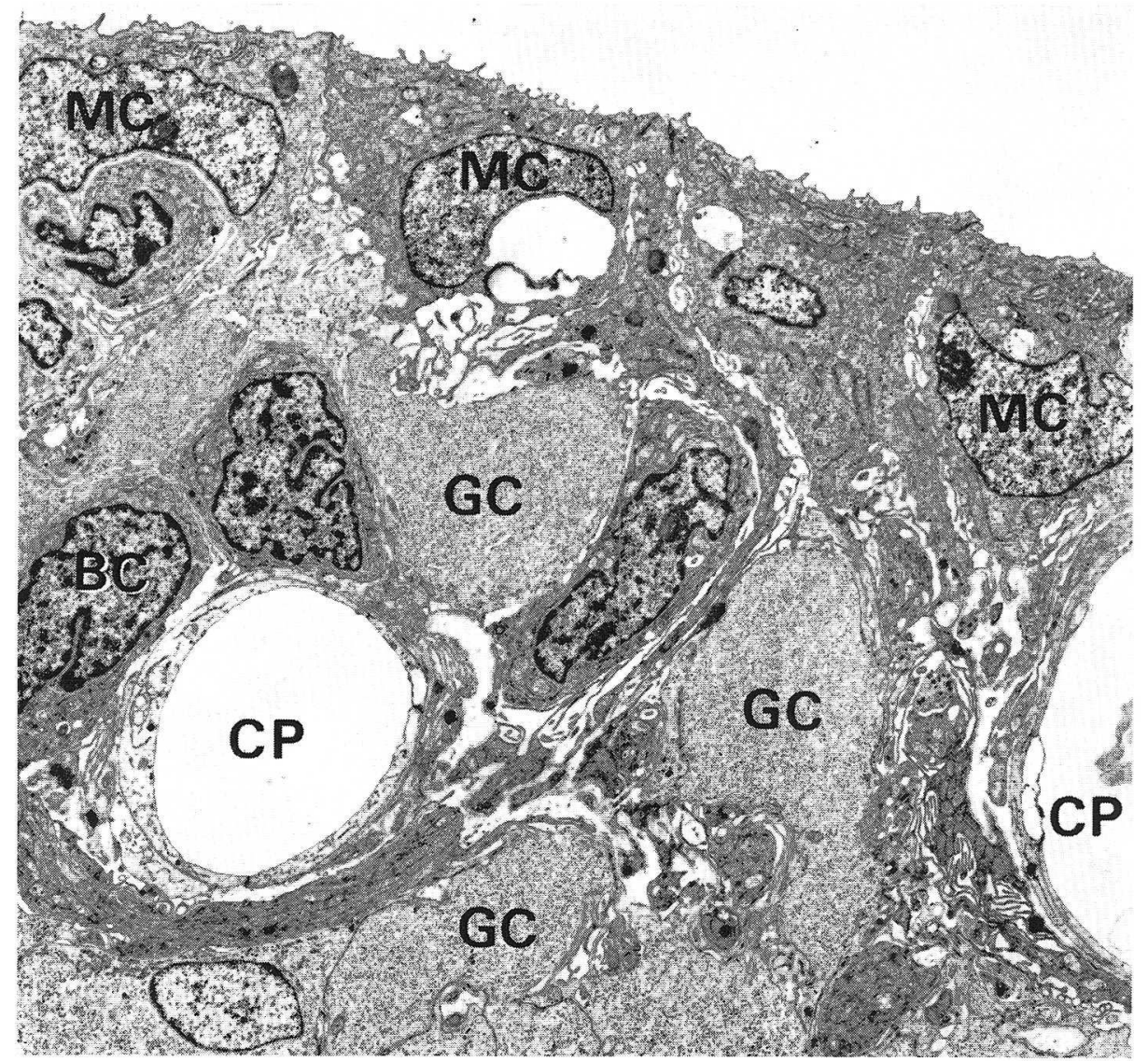

Fig. 11. The stria vascularis of the spiral prominence at 5 months is shown. Marginal cells $(M C)$ of the epithelium are provided with short microvilli and characterized by extensive lateral and basal infoldings of the plasma membrane. The cytoplasmic projections surround intraepithelial capillaries $(C P)$ as vascular feet. Cells accumulated with glycogen particles $(G C)$ are found in and below the epithelium. $B C$ basal cell. $\times 3,400$

inner hair cells were observed at 7 months. Most of them are of the efferent type, while afferent synapses were rarely found at this period. The outer hair cells are almost entirely surrounded by the Deiters' cells at 5 months (Fig. 4). However, a wide intercellular space between the outer hair and Deiters' cell appears as in the case in the adult organs at 7 months: The upper end of the former cell is wedged between phalanges of the latter cell (Fig. 9, 10).

\section{The stria vascularis}

The stria vascularis lining the external wall of the cochlear ducts was examined only in the 5 month specimen. The stratified epithelium consists of two or more cell layers, and the invasion of blood vessels into the epithelial layer as the "intraepithelial capillaries" has already occurred (Fig. 11). Prominent infoldings of the lateral cell membrane are apparent in most epithelial cells and the thin laminar 

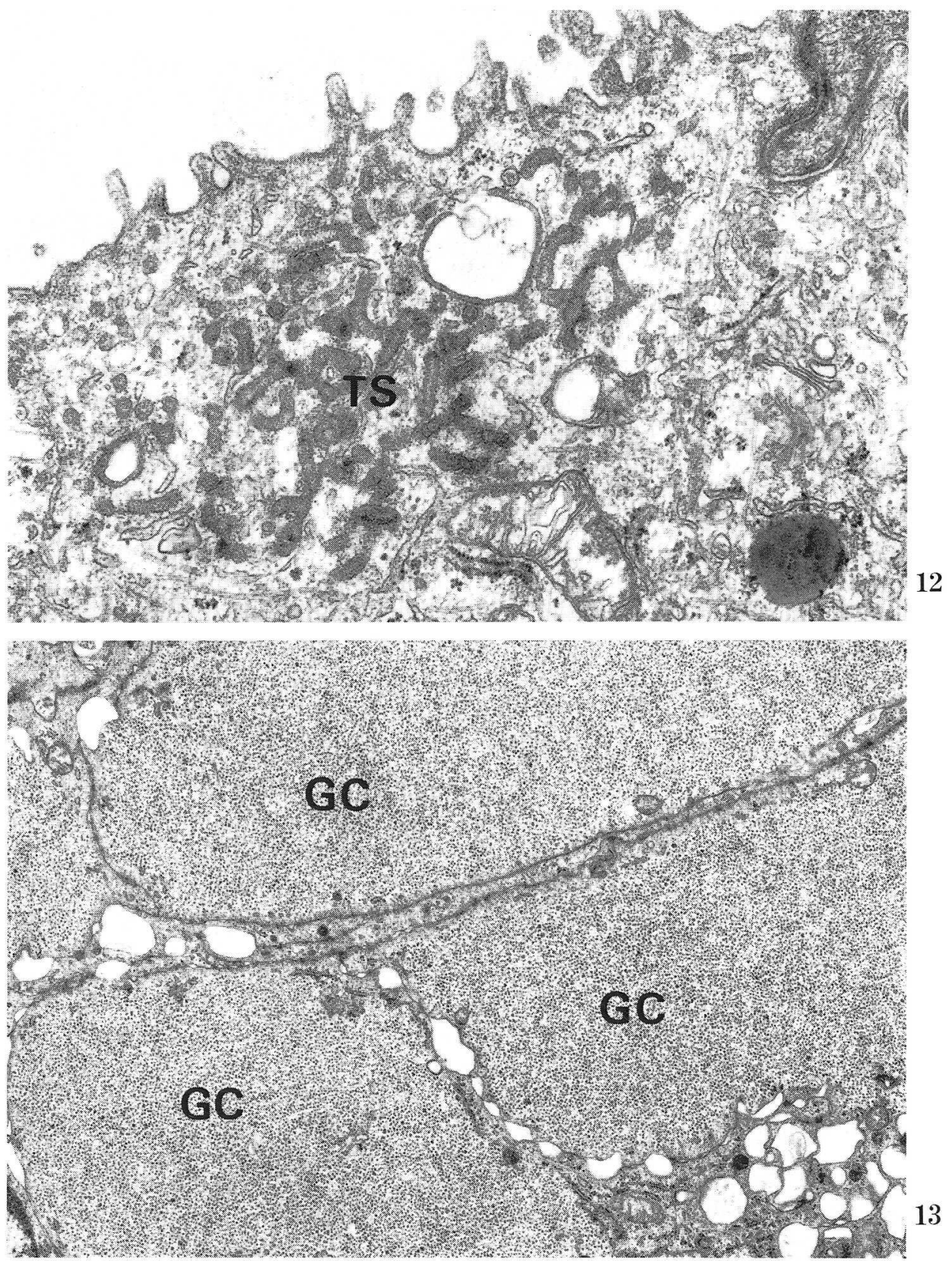

Fig. 12. A thick-walled tubular membrane system (TS) exists in the apical region of a marginal cell. The tubules contain electron dense amorphous contents. $\times 24,000$

Fig. 13. A more highly magnified micrograph showing cells accumulated with glycogen particles $(G C) . \quad \times 8,000$ 
cytoplasmic processes, especially of the cells located in the basal region of the epithelia, surround these capillaries as vascular feet.

The cells directly facing the cochlear lumen (differentiating marginal cells) are rather cuboidal in shape and their apical surface is provided with a few short microvilli. The luminal cell membrane is associated with a fuzzy coat and measures approximately $120 \AA$ thick. Coated vesicles, possibly originating from the invagination of the apical plasma membrane, are already numerous as in the case of adult specimens. The neighboring marginal cells are conjugated to each other by zonulae and maculae adherentes but junctions in the manner of zonulae occuludentes were not observed yet.

The most interesting feature of the differentiating marginal cells is the existence of thick walled tubular membranes in their cytoplasm (Fig. 12). These smooth tubular membranes have a rether constant diameter of approximately $0.06 \mu \mathrm{m}$ and are clearly distinguishable from ordinary smooth endoplasmic reticulum by their thicker limiting membrane and electron dense amorphous contents. The inner aspect of their limiting membrane is associated with a fuzzy coat similar to the outer aspect of the apical plasma membrane. However, the direct continuation of these tubular systems with the apical plasma membrane was not demonstrated in the present study.

A large number of cells, which show a positive reaction with PAS staining, were observed in and below the epithelia. By TEM observation, their cytoplasm is almost completely occupied by glycogen particles. These cells sometimes possess narrow cytoplasmic processes which are in contact with each other (Fig. 13), or with the neighboring epithelial cells with many desmosomes.

\section{DISCUSSION}

Bulbous cytoplasmic projections from the cuticular plate of the hair cells in the present observation are thought to be similar to those reported in the postnatal kitten by SEM although their detailed internal structures were not shown by TEM (Hoshino, 1974). The present TEM observation clearly demonstrated that these structures are projections of the cuticular plate, and the auditory stereocilia and a single kinocilium are differentiated from them. In his SEM and TEM observations of the macula sacculi of the postnatal chicken, Hirokawa (1975) has also demonstrated similar structures to ours. However, he only stated that "kinocilium and several stereocilia protrude from a large globular protrusion or fuse with it." By our electron microscopy, especially of cross or oblique sections of these bulbous structures, it is apparent that axial filaments of auditory stereocilia are synthesized in these bulbous structures and new stereocilia are originated from them in the fetal condition. The observation also suggests that the bulbous structures gradually reduce their size and might be removed from the main cell surface after the distribution of the stereocilia has been accomplished on each hair cell.

A single kinocilium is also distributed at the center of the bulbous structures. However, our observations do not reveal how the cilium disappears in adults. Although entirely speculative, the loss of the cilium might be associated with the loss of the bulbous structures. 
The fine structure of the stria vascularis has been observed in various mammals by many authors (ENGSTRöm, Suöstrand and SPoendlin, 1955; SMith, 1957; ChOU, 1961; YAmamoto and NAKAI, 1964; Rodriguez-Echandia and Burgos, 1965; Hinojosa and RodRIGUEz-Echandia, 1966). However, electron microscope observation of its fetal features has not been done yet. It is widely accepted that the stria vascularis participates in production of the endolymph. At 5 months, a great increase in area of the cell surface by the lateral and basal cytoplasmic infoldings was already observed in the differentiating marginal cells as is generally pointed out in adult specimens. Thus, we have no inconsistencies with the hypothesis that the marginal cells have a primary role for ion transport mechanism.

The present observation yields additional information as to the fine structure of the marginal cells. Smooth surface tubular membranes exist in their apical cytoplasm. These tubules are clearly distinguishable from ordinary smooth endoplasmic reticulum by their thicker limiting membrane and electron dense amorphous contents. The extensive amplification of the apical plasma membrane involved in active transport of ions has been reported in salt secreting cells (DOyLE, 1960; BULGER, 1963; Philpott and Templeton, 1964) and in chloride cells (Philpott and Copeland, 1963; Conte, 1969). In the cochlear duct, Rodriguez-Echandia and Burgos (1965) have suggested that the unusually high concentration of potassium ions in the endolymph is due to the presence $\mathrm{cf}$ a specialized structure somewhere in the stria vascularis for secretion of this ion. Although we have not determined the direct continuity of the tubular system with the cochlear lumen by marker experiments, these structures may represent such a "specialized structure" as was supposed by the previous authors. At any rate, the present observation adds further weight to the hypothesis by Rodriguez-Echandia and Burgos (1965) that the stria vascularis may be involved not merely in transduction of the endolymph into the cochlear lumen but also in secretion of some ionic compositions into the endolymph.

Glycogen accumulated cells are thought to exist only in the fetal condition, since such cells have not been described in adult specimens. However, the significance of thes cells is difficult to imagine from the limited specimens in the present study. Whether they might be involved in production of some compositions of the endolymph or not remains uncertain. More detailed morphological information as to their differentiation and degeneration is necessary to clarify their exact role.

\section{ヒト胎児蝸牛管の電子顕徽鏡的観察}

藤本淳, 山本硬治, 早㴊一郎, 吉塚光明

\footnotetext{
ヒト胎児蝸牛管のコルチ器および血管条を 走查および透過電子顕微鏡（SEM, TEM）で 観察した.

コルチ器の内および外有毛細胞表面には，仔ネコの SEM 観察で報告されたものと同様 の囊状構造が存在するが，TEM 像ではこれらは小皮板の一部が突出したものであり， 5 力月例でみると, 形質膜に沿って 聴毛軸線維がさかんに形成され，聴毛が囊状構造から 派生していく。しかし，7 力月例では 囊状構造は縮少および変性し，上記のような過程は
} 


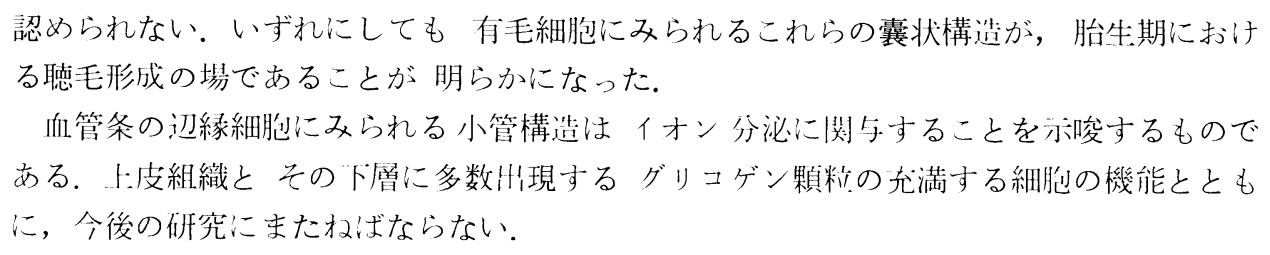

\section{REFERENCES}

Bredberg, G., H. W. Ades and H. Engström : Scanning electron microscopy of the normal and pathologically altered organ of Corti. Acta oto-laryngol., Suppl. 301: 1-48 (1972).

Bulger, R. E.: Fine structure of the rectal (salt secreting gland of the spiny dogfish, Squalus acanthias. Anat. Rec. 147: 95-127 (1963).

Chou, J. T. Y.: A cytological and histochemical study of the stria vascularis of the guinea-pig's ear. Quart. J. microsc. Sci. 102: 75-82 (1961).

Conte, F. P.: Salt secretion. In: (ed. by) W. S. Hoar and D. J. Randall: Fish physiology. Academic Press, New York-London, 1969 (vol. 1, p. 241-292).

Corti, A.: Recherches sur l'organe de l'ouie des mammaifères. Z. wiss. Zool. 3: 109-169 (1851).

Doyle, W. L.: The principal cells of the salt-gland of marine birds. Exp. Cell Res. 21: 386-393 (1960).

Engström, H.: On the double innervation of the sensory epithelia of the inner ear. Acta otolaryngol. 49: 109-118 (1958).

—: Inner ear studies II. Acta oto-laryngol., Suppl. 319: 1-66 (1975).

Engström, H., H. W. Ades and J. E. Hawkins: Structure and function of the sensory hairs of the inner ear. J. Acoust. Soc. Amer. 34: 1356-1364 (1962).

Engström, H., F. S. Sjöstrand and H. Spoendlin : Finstruktur der Stria vascularis beim Meerschweinchen. Pract. oto-rhinolaryngol. 17: 69-79 (1955).

Friedmann, I.: The innervation of the developing fowl embryo otocyst in vivo and in vitro. Acta oto-laryngol. 67: 224-238 (1969).

Hinojosa, R. and E. L. Rodriguez-Echandia : The fine structure of the stria vascularis of the cat inner ear. Amer. J. Anat. 118: 631-663 (1966).

Hirokawa, N.: The ultrastructural studies of the macula sacculi of chicken. In: (ed. by) E. Yamada: Proceedings of 10th Int. Congr. Anat., Sci. Counc. Jap., Tokyo, 1975, (p. 331).

Hoshino, T: Tectorial membrane and otolithic membrane of pigeon inner ear. A scanning electron microscope study. Arch. histol. jap. 35: 141-152 (1973).

: Relationship of the tectorial membrane to the organ of Corti. A scanning electron microscope study of cats and guinea pigs. Arch. histol. jap. 37: 25-39 (1974).

Iurato, S.: Submicroscopic structure of the membranous labyrinth. 2. The epithelium of Corti's organ. Z. Zellforsch. 52: 259-298 (1961).

Kimura, R. S. : Hairs of the cochlear sensory cells and their attachment to the tectorial membrane. Acta oto-laryngol. 61: 55-72 (1966).

Lim, D. J. : Fine morphology of the tectorial membrane. Arch. Otolaryngol. 96: 199-215 (1972).

Philpott, C. W. and D. E. Copeland: Fine structure of chloride cells from three species of Fundulus. J. Cell Biol. 18: 389-404 (1963).

Philpott, C. W. and J. R. Templeton: A comparative study of the histology and fine structure of the nasal salt secreting gland of the lizard, Dipsosaurus. Anat. Rec. 148: 394-395 (1964).

Rodriguez-Echandia, F. L. and M. H. Burgos: The fine structure of the stria vascularis of the guinea-pig inner ear. Z. Zellforsch. 67: 600-619 (1965). 
Smith, C. A.: Structure of the stria vascularis and the spiral prominence. Ann. Otol. Rhinol. Laryngol. 66: 521--536 (1957).

: Electron microscopy of the inner ear. Ann. Otol. Rhinol. Laryngol. 77: 629-643 (1968).

Smith, C. A. and F. S. Sjöstrand: Structure of the nerve endings on the external hair cells of the guinea-pig cochlea as studied by serial sections. J. Ultrastr. Res. 5: 523-556 (1961).

Wersäll, J., A. Flock and P. G. Lundquist: Structural basis for directional sensitivity in cochlear and vestibular sensory receptors. Cold Spring Harbor Symp. Quart. Biol. 30: 115-132 (1965).

Yamamoto, K. and Y. Nakai : Electron microscopic studies on the function of the stria vascularis and the spiral ligament in the inner ear. Ann. Otol. Rhinol. Laryngol. 73: 333-347 (1964).

\author{
藤 本 淙 \\ 厂807 北九州市八幡西区医生:ケ丘 1-1 \\ 産業医科大学 \\ 第二解剖学教空
}

\author{
Prof. Sunao Fujimoto \\ Department of Anatomy \\ University of Occupational and Environ- \\ mental Health School of Medicine \\ Kitakyushu, 807 Japan
}

